\title{
Perbandingan Perkembangan Pengelolaan Pantai Pandawa Sebagai Daya Tarik Wisata Di Desa Kutuh, Kecamatan Kuta Selatan, Kabupaten Badung
}

Ni Kadek Dina Medinawati a, 1, Ida Bagus Suryawana, 2

${ }^{1}$ soramedina170594@gmail.com, 2idabagussuryawan@unud.ac.id

a Program Studi S1 Destinasi Pariwisata, Fakultas Pariwisata,Universitas Udayana, Jl. Dr. R. Goris, Denpasar, Bali 80232 Indonesia

\section{Abstract}

Pandawa beach officially launched by village governor in 2011, that then accepted as a tourist attraction by Badung government in 2014. As a tourist attraction, Pandawa beach had been given much changes just for five period of time. On it's developing, on year of 2016 researcher heard some issues like changing management and divisioning tourist area at beach. According from these issues, the purposed of this reasearch is to compare management development at Pandawa beach in 2011 with 2016, that hope could give some depicts management changes that had been done by Pandawa beach management. This reasearch used some data collected technic, they were interview, observation, and documentation. The informants divided by based informant whom is Bendesa Adat Kutuh and key informants whom are manager and adiministration staff in Pandawa beach management. Analyze data was used comparative overtime analysis. The result of this comparison shows there are changes at each management function in Pandawa beach development, therefore from planning side, organizing, directing, and controlling. In planning side, alteration happened at nature attraction aspec, amenity, accessibility, tourist activity pattern, and institutional. Approach model which is use in Pandawa managemnt is model in form of the element manager's governing body. To face these developments, manager of Pandawa beach must do some adviser for human resources intensively, re-evalution about future construction at beach area, and clarity management portion to stakeholders.

Keywords: pandawa beach, beach development, management comparison

\section{PENDAHULUAN}

Setiap daerah memiliki potensi yang bisa dikembangkan untuk menunjang perekonomian dan memajukan kesejahteraan masyarakat setempat. Begitu pula dengan Desa Kutuh yang terletak di Kecamatan Kuta Selatan, Kabupaten Badung memiliki potensi besar pada alam pantainya. Diketahui awalnya Desa Kutuh adalah desa pemekaran dari Desa Ungasan yang telah diresmikan oleh Bupati pada tahun 2002. Setelah menjadi desa definitif, Desa Kutuh berusaha mandiri untuk memajukan desa dengan mengandalkan potensi - potensi yang ada. Salah satunya adalah Pantai Pandawa. Dahulu, Pantai Pandawa dikenal dengan nama Pantai Melasti atau Pantai Kutuh oleh masyarakat lokal, karena fungsi pantai saat itu hanya sebatas acara ritual melasti. Penduduk Kutuh mengandalkan Pantai Pandawa sebagai pertanian rumput laut. Setelah Desa Kutuh mandiri, pendudukpun melakukan pemotongan jalan menuju pantai ini. Diketahui, pemotongan jalan ini mendapatkan kerjasama dari PT. Ragawisata sebagai penyedia akomodasi. Dengan adanya pemotongan ini, Pantai Pandawapun mulai berkembang. Jumlah petani rumput laut meningkat dan terlihat adanya kunjungan pelancong. Pihak desa yang melihat potensi tersebut, akhirnya mengembangkan Pantai Pandawa menjadi daya tarik wisata. Hingga pada tahun 2011, pihak Desa Adat dan Desa Dinas melakukan launching pada pantai ini. Perkembangan Pantai Pandawa dapat dikatakan sangat cepat. Terlihat dari jumlah kunjungan wisatawan yang semakin ramai setiap tahunnya. Di tahun 2013 jumlah kunjungan wisatawan diketahui 399.263 jiwa, pada tahun 2014 mencapai 1.374.359 jiwa dan mengalami penigkatan di tahun 2015 mencapai hingga 1.617.374 jiwa (sumber : laporan jumlah kunjungan ke Pantai Pandawa 2016). Selain itu, di tahun ini berdasarkan observasi awal, peneliti menemukan adanya pembangunan resort dan kenaikan tarif masuk hingga 100\% dalam kurun waktu sebulan. Peneliti juga mendengar isu bahwa Pantai Pandawa kini dikelola oleh PEMDA (Pemerintah Daerah) dan akan ada pembagian zona bagi wisatawan. Maka dari itu, peneliti ingin membandingkan perkembangan pengelolaan pada Pantai Pandawa saat pertama kali launching di tahun 2011, dengan Pantai Pandawa di tahun 2016 ini. Berdasarkan dari latar belakang tersebut, adapun rumusan masalah yang diambil yaitu bagaimana perbandingan perkembangan pengelolaan Pantai Pandawa pada tahun 2011 dan tahun 
2016. Sesuai dengan permasalahan, maka tujuan penelitian ini adalah untuk mengetahui perbandingan perkembangan pengelolaan Pantai Pandawa pada tahub 2011 dan tahun 2016.

\section{KEPUSTAKAAN}

Beberapa kajian penelitian sebelumnya yang dijadikan pembanding dalam penelitian ini yaitu penelitian oleh Mulya, dkk (2013) dengan judul "Implementasi Kebijakan Alokasi Dana Desa dalam Pengelolaan Potensi Desa Kutuh Kecamatan Kuta Selatan Kabupaten Badung", yang telah memberikan hasil bahwa implementasi ADD Desa Kutuh sudah berjalan dengan baik walaupun memiliki hambatan dalam penyalurannya. Kemudian penelitian berjudul "Peranan Desa Adat dalam Pengembangan dan Pengelolaan Pantai Pandawa sebagai Kawasan Pariwisata di Desa Kutuh" oleh Tresna Dewi,dkk (2014) memberikan hasil bahwa peranan Desa Adat sendiri berupa pembangunan jalan menuju Pantai dan dalam pengembangan Pantai Pandawa berdampak positif terhadap perekonomian masyarakat. Penelitian ini memiliki lokus yang sama dengan penelitian sebelumnya yaitu sama - sama di Desa Kutuh, spesifiknya di Daya Tarik Wisata Pantai Pandawa. Namun fokus kajian yang dibahas pada penelitian ini berbeda. Pada penelitian berikut lebih ditekankan pada perkembangan pengelolaan Pantai dalam kurun waktu lima tahun terakhir. Sehingga, penelitian ini masih memiliki kesempatan dan bisa untuk dilakukan.

Beberapa konsep yang digunakan dalam penelitian ini yaitu konsep pengelolaan dengan menggunakan fungsi - fungsi manajemen menurut Irma Nilasari dan Sri Wiludjeng (2006 dalam Pratamasidi, 2012) yaitu Perencanaan ( Planning), Organisasi (Organizing), Pengarahan (Directing), dan Pengendalian (Controlling). Konsep pengelolaan digunakan untuk menjabarkan aspek-aspek manajemen di Pantai Pandawa yang dilakukan oleh pengelola. Kemudian, konsep daya tarik wisata menurut Ismayanti (2010). Tinjauan perencanaan kepariwisataan alam yang terdiri dari karakteristik atraksi alam, amenitas, aksesibilitas, pola kegiatan wisatawan, dan kelembagaan. Aspek - aspek tersebut akan dijabarkan dalam indikator planning pada fungsi manajemen. Konsep model pengelolan oleh
Prasiasa (2013) yang terdiri dari 4 model yaitu unsur pengelola dari pranata kemasyarakatan lokal, unsur pengelola pelaku pariwisata, unsur pengelola pemerintah, unsur pengelola berupa badan pengelola.

\section{METODE PENELITIAN}

Sumber data dalam penelitian ini meliputi sumber data primer dan data sekunder. Sumber data primer dalam penelitian ini meliputi data kondisi di lapangan, serta informasi yang langsung diperoleh dari informan terkait pengelolaan di Pantai Pandawa. Sedangkan data sekunder sendiri meliputi data kunjungan wisatawan di Pantai Pandawa tahun 2016 serta beberapa informasi dari media massa dan brosur. Teknik Pengumpulan data untuk penelitian ini menggunakan teknik observasi, wawancara, dan dokumentasi. Teknik observasi digunakan untuk melihat kondisi dilapangan saat ini seperti kegiatan wisatawan, tingkah laku masyarakat lokal penyedia jasa pariwisata, fasilitas serta pembangunan yang telah dilakukan saat ini. Teknik wawancara digunakan untuk mencari data berupa penjelasan pengelolaan di tahun 2011 dan pengelolaan di tahun 2016 serta perencanaan kedepannya, dan teknik dokumentasi guna membantu dalam pencarian data berupa laporan kunjungan wisatawan, peraturan pengelola, dan sejarah pantai Pandawa. Pada penelitian ini, teknik analisis data yang digunakan adalah perbandingan antarwaktu atau komparif overtime. Teknik komparatif menurut Burhan Bungin (2012) yaitu teknik untuk mebandingkan berbagai kejadian yang terjadi di lapangan selama peneliti melakukan penelitian tersebut. Perbadingan itu bisa berupa perbandingan antarwaktu, antarruang, antartindakan, dan lainnya. Perbandingan antarwaktu disini adalah perbandingan perkembangan pengelolaan di Pantai Pantai Pandawa di tahun 2011 dengan tahun 2016.

\section{IV.HASIL DAN PEMBAHASAN}

Lokasi Pantai Pandawa terletak di Desa Kutuh, Kecamatan Kuta Selatan, Kabupaten Badung. Membutuhkan waktu kurang lebih 60 menit dari Denpasar atau 15 menit dari Garuda Wisnu Kencana. Pantai Pandawa telah ditetapkan menjadi salah satu daya tarik wisata unggul di Kabupaten dengan SK Bupati Badung 
No.43 tahun 2014. Luas permukaan permukaan pasir Pantai Pandawa sampai titik pasang terendah adalah $32 \mathrm{~m}^{2}$ dan memiliki panjang bentangan pantai hingga 1700 meter (sumber : wawancara dengan Bapak Letra, tahun 2016). Batasan sebelah utara pantai adalah Jimbaran, Sawangan di sebelah timur, Samudra Indonesia di sebelah selatan, dan Desa Ungasan di sebelah barat. Pantai memiliki ciri khas berupa patung Panca Pandawa yang berdiri bejejer di sepanjang jalan pantai, dilingkari tebing kapur yang besar yang menambah kesan 'pantai tersembunyi', pasir putih, dan air yang masih jernih.

Diketahui bahwa Pantai Pandawa pertama kali dilaunchingkan oleh pihak Desa Adat bersama Desa Dinas melalui LPM (Lembaga Pemberdayaan Masyarakat) di tahun 2011. Saat itu, Pantai Pandawa masih dikenal dengan komoditi rumput lautnya. Namun, seiring dengan semakin terkenalnya Pantai Pandawa dan kunjungan wisatawan yang meningkat, pembangunan fasilitas penunjang untuk wisatawan mulai dibangun. Peralihan mata pencaharianpun terjadi. Pada tahun 2016 ini, sesuai dengan observasi lapangan, hampir seluruh masyarakat lokal menjadi penyedia jasa dan membuka kios di pinggiran pantai Pandawa. Kenaikan tiket juga terjadi semenjak Pemerintah Daerah masuk dalam pengelolaan Pantai Pandawa. Harga tiket saat ini mencapai Rp.8000,00 dewasa, domestik anak - anak Rp.4000,00, wisatawan asing Rp.15.000, dan wisatawan asing anak-anak Rp. 10,000.

Pengelolaan di Pantai Pandawa dibandingkan dari tahun awal launching yaitu tahun 2011 dengan keadaan pantai saat ini di tahun 2016. Perbandingan ini dilakukan berdasarkan dari perubahan fisik Pantai Pandawa secara cepat dan adanya beberapa isu perubahan pengelola pantai. Berikut adalah tabel perbandingan antarwaktu dengan jarak waktu lima tahun di Pantai Pandawa.

Tabel 4.1 Perbandingan Pengelolaan Pantai Pandawa

\begin{tabular}{|l|l|l|}
\hline \multicolumn{1}{|c|}{$\begin{array}{c}\text { Fungsi } \\
\text { Pengelolaan }\end{array}$} & \multicolumn{1}{|c|}{ Tahun 2011 } & \multicolumn{1}{c|}{ Tahun 2016 } \\
\hline $\begin{array}{l}\text { Perencanaan } \\
\text { (Planning) }\end{array}$ & $\begin{array}{l}\text { a). Atraksi Wisata : } \\
\text { pantai Pandawa dan } \\
\text { pertanian rumput }\end{array}$ & $\begin{array}{l}\text { a) Atraksi Wisata : } \\
\text { pantai Pandawa, } \\
\text { wisata edukasi } \\
\text { garden coral, dan } \\
\text { laut. Amenitas : } \\
\text { bertunjukkan seni }\end{array}$ \\
& $\begin{array}{l}\text { b). Amung yang masih } \\
\text { wecak dance. } \\
\text { sedikit dan kamar }\end{array}$ & b). Amenitas : telah \\
\hline
\end{tabular}

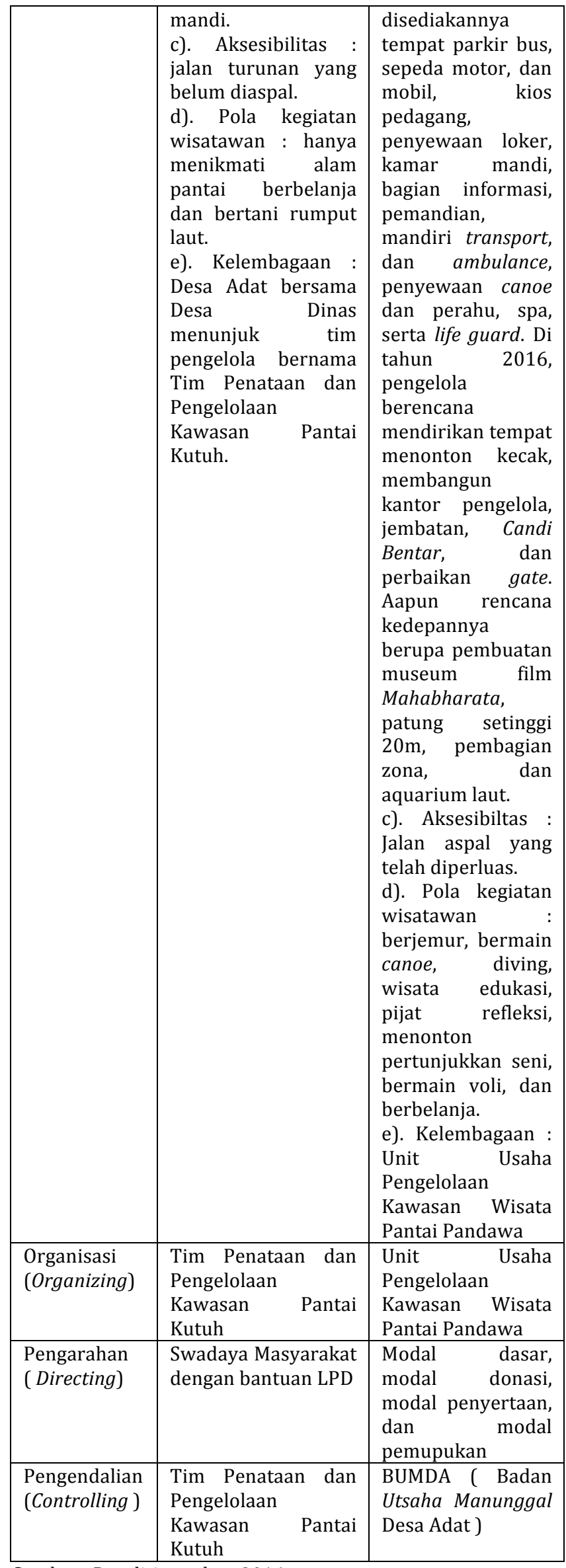

Sumber : Penelitian tahun 2016 
Perbandingan pengelolaan Pantai Pandawa pada tahun 2011 dan tahun 2016 dapat dijabarkan sebagai berikut;

\section{a). Perencanaan (Planning)}

Pada perencanaan di tahun 2011, atraksi wisata yang ada hanyalah atraksi alam pantai dan pertanian rumput laut, fasilitas yang telah disediakan berupa warung dan kamar mandi. Aksesibilitas yang sudah dibangun masih berupa jalan batu kapur. Pola kegiatan wisatawan pun tidak banyak, hanya sekedar menikmati pemandangan pantai dan berbelanja. Masyarakat masih banyak bertani rumput laut, maka dari itu sampah rumput laut pun terlihat disepanjang bibir pantai. Kelembagaan yang mengatur yakni pengelola yang ditunjuk langsung oleh Desa Adat bersama dengan Desa Dinas yang kemudian diberi nama Tim Penataan dan Pengelolaan Kawasan Pantai Kutuh. Sedangkan di tahun 2016 ini, atraksi wisata sudah mulai ada campur tangan manusia seperti wisata edukasi garden coral, dan pertunjukkan seni Kecak dance. Amenitas yang sudah disediakan sampai saat ini yaitu tempat parkir bus, sepeda motor, dan mobil, kios pedagang, penyewaan loker, kamar mandi, bagian informasi, pemandian, mandiri transport, dan ambulance, penyewaan canoe dan perahu, spa, serta life guard. Pola kegiatan wisatawan pun semakin beragam sesuai dengan fasilitas dan atraksi wisata yang disuguhkan di Pantai Pandawa, yaitu berjemur, bermain canoe, diving, wisata edukasi, pijat refleksi, menonton pertunjukkan seni, bermain voli, dan berbelanja. Kelembagaan yang mengatur semua ini juga sudah berganti nama yakni Unit Usaha Pengelolaan Kawasan Wisata Pantai Pandawa.

\section{b). Organisasi (Organizing)}

Pada tahun 2011 organisasi yang mengatur seluruh kegiatan di Pantai Pandawa bernama Tim Penataan dan Pengelolaan Kawasan Pantai Kutuh yang ditunjuk langsung oleh Desa Adat bersama dengan Desa Dinas. Kemudian di tahun 2016 ini, pengelola sudah memiliki badan organisasi yang lebih resmi bernama Unit Usaha Pengelolaan Kawasan Wisata Pantai Pandawa. Unit usaha ini memiliki 309 anggota dengan jumlah pegawai tetap 50 orang (sumber : wawancara tahun 2016).
Adapun objek wisata yang dikelola menjadi daya tarik wisata yaitu Ngampan dengan situs Goa Pandawa, pantai dengan pasir putih, agrowisata rumput laut, konservasi terumbu karang, wisata spiritual, dan wisata budaya. Jasa pariwisata yang dikelola oleh pihak ini berupa jasa transportsi wisata, jasa makanan dan minuman (kuliner), jasa penyelenggaraan kegiatan atraksi budaya, jasa fasilitasi penyelenggaraan wedding, jasa fasilitasi penyelenggaraan party, jasa fasilitasi penyelenggaraan shooting, outbond, jasa wisata tirta, jasa rekreasi, jasa penjualan souvenir, jasa spa, jasa akomodasi, jasa informasi pariwisata, jasa wisata spiritual dan jasa MICE (Meeting, Incentive, Conferencing, Exhibitions).

\section{c). Pengarahan ( Directing )}

Pada tahun 2011 pengarahan dilakukan dengan mengandalkan swadaya masyarakat dan bantuan dana dari LPD (Lembaga Perkreditan Desa), namun pada tahun 2016 dana sudah dapat dikelola dan dibagi menjadi beberapa bagian, meliputi modal dasar, modal donasi, modal penyertaan, dan modal pemupukan. Pembinaan dilakukan melalui kegiatan pengaturan, bimbingan, penyuluhan, teguran, dan peringatan. Pihak pengelola juga melakukan kerjasama dengan pihak trael, Himpunan Pramuwisata Indonesia, Rumah Sakit Surya Husadha, PT. Ragawisata, PT.Agung, ASITA (Association of the Indonesian Tours and Travel), dan pihak lainnya.

\section{d). Pengendalian ( Controlling )}

Berkaitan dengan Pengendalian atau pengawasan di Pantai Pandawa, dilakukan oleh Tim Penataan dan Pengelolaan Kawasan Pantai Kutuh bersama Desa Adat pada tahun 2011, namun di tahun 2016 manajemen Unit Usaha Pengelolaan Kawasan Pantai Pandawa sendiri diawasi oleh BUMDA (Bhaga Utsaha Manunggal Desa Adat ), karena BUMDA yang memprakarsai terbentuknya manajemen Unit Usaha Pengelolaan Kawasan Wisata Pantai Pandawa. BUMDA adalah sebuah lembaga orgaisasi masyarakat yang bertugas mengatur seluruh potensi Desa Kutuh. Sangsi yang dikenakan bagi pelanggar peraturan yaitu peringatan lisan, peringatan tertulis, pemberhentian sementara, hingga pemberhentian tetap.

\section{KESIMPULAN DAN SARAN 5.1 Kesimpulan}


Berdasarkan penjabaran di atas, maka dapat disimpulkan bahwa pengelolaan dalam fungsi perencanaan baik belum maupun yang sudah dilaksanakan, pengorganisasian, pengarahan, dan pengawasan mengalami perubahan dalam kurun waktu lima tahun. Pada indikator planning mengalami banyak perubahan. Hal ini dikarenakan disamping pertanian rumput laut tidak lagi efektif berkembang, pihak pengelola juga melakukan pembangunan kios -kios usaha untuk masyarakat desa sehingga masyarakat Desa Kutuh diharapkan dapat mengembangkan perekonomian mereka melalui usaha yang dibuka. Tidak hanya kios, pengelola juga melakukan perekrutan untuk posisi yang dibutuhkan untuk mengelola Pantai Pandawa. Pihak pengelola sendiri juga memiliki proker memanfaatkan potensi Pantai Pandawa dan Desa Kutuh, sehingga terbentuklah wisata edukasi garden coral dan pertunjukkan seni. Seiring waktu dengan bertambahnya jumlah kunjungan wisatawan, maka perbaikan juga perlu dilakukan pada amenitas dan aksesibilitas.

Karena Pantai Pandawa memiliki badan pengelola bernama Unit Usaha Pengelolaan Kawasan Wisata Pantai Pandawa yang diatur oleh organisasi BUMDA ( Bhaga Utsaha Manunggal Desa Adat), bisa dikatakan pendekatan pengelola menggunakan model unsur unsur pengelola berupa badan pengelola.

Saran yang dapat peneliti berikan kepada pengelola adalah meningkatkan mutu dan pelatihan sumber daya manusia, melakukan evaluasi ulang mengenai dampak jangka panjang daripada pembangunan pantai, dan memberikan porsi - porsi yang jelas kepada stakeholder yang terlibat walaupun Desa Adat sebagai pemegang kuasa tertinggi. Penelitian selanjutnya yang bisa disarankan dapat berupa hubungan kerjasama antar stakeholder karena Pantai Pandawa masih dalam masa pengembangan, jadi ada kemungkinan akan ada penambahan stakeholder atau perubahan pola kerjasama antar stakeholder.

\section{DAFTAR PUSTAKA}

Bungin, Burhan. 2012"Analisis Data Penelitian Kualitatif".Jakarta: PT Raja Grafindo Persada

Ismayanti, 2010."Pengantar Pariwisata". Jakarta : PT.Gramedia Widiarsana Indonesia

Laporan jumlah kunjungan ke Pantai Pandawa 2016
Mulya, Ni Putu, Bandiah \& Wiwin, Kadek.2013. "Implementasi Kebijakan Alokasi Dana Desa dalam Pengelolaan Potensi Desa Kutuh Kecamatan Kuta Selatan Kabupaten Badung".Denpasar:Fakultas Ilmu Politik dan Ilmu Sosial Universitas Udayana

Prtamasidi, Rayhan. 2012."Tinjauan Pelaksanaan Program Pelatihan Karyawan Pada PT.Nusantara Turbin dan Propulsi Bandung".Bandung: Fakultas Bisnis dan Manajemen Universitas Wisyatama

Prasiasa, Dewa Putu Oka. 2013"Destinasi Pariwisata Berbasis Masyarakat".Jakarta: Salemba Humanika

Perarem Desa Adat Kutuh. 2014."Pembentuk dan Pengelolaan Bhaga Utsaha Manunggal Desa Adat (BUMDA) Desa Adat Kutuh".Desa Kutuh: Desa Adat Kutuh

Perarem Desa Adat Kutuh. 2014."Pembentukan dan Pengelolaan Unit Utsaha Kawasan Wisata Pantai Pandawa".Desa Kutuh: Desa Adat Kutuh

Tresna Dewi,Ni Luh Putu, Arya Sunu, I Gst Ketut, \& Sanjaya, Dewa Bagus.2014." Peranan Desa Adat dalam Pengembangan dan Pengelolaan Pantai Pandawa sebagai Kawasan Pariwisata di Desa Kutuh".2016: http://ejournal.undiksha.ac.id/index.php/JJPP/artic le/view/4544/(diakses: 2016 ,Januari 20) 